\author{
Antonio Gallardo Gracia \\ ORCID: 0000-0002-3651-4148 \\ Universität Würzburg
}

\title{
Dear White People Vol. 2: Social networking as an enforcing tool for racial inequality
}

Abstract: Recently, social networking sites have been used as a means of spreading an alarming narrative under the premise of freedom of speech, through enraging, provocative and harmful messages. Some of them, posted by powerful and influential people, have empowered a group of individuals who have spoken up and expressed their approval of said messages through increasingly harsher language, as well as violent actions. Some of them were racist in tone, and increasingly widespread on several social media platforms, such as Twitter, where the issue of racial inequality fuels increasing division and hatred. Dear White People is a Netflix series, based on a 2014 film of the same title, depicting Winchester University, an ethnically diverse college in the United States of America, where a conflict along racial lines erupts. At the same University, Samantha White, a junior Media Studies major, begins hosting a radio show called "Dear White People", addressed to Caucasian students in order to make them aware of what Blackness means in a judgmental, predominantly white society. The aim of this article is to present how influential social networking is in society by using the example of Dear White People Vol. 2, as well as to illustrate how the issue of racism increases in magnitude through a narrative that spreads and encourages individuals to take verbal and physical actions against the black minority.

Keywords: Dear White People, social networking, racism, Netflix, television, politics, identity

\section{Introduction}

Recently, social networking sites have been used as a means of spreading an alarming narrative under the premise of freedom of speech, through enraging, provocative and harmful messages. Some of them, posted by powerful and influential people, have empowered a group of individuals who have spoken up and expressed their approval of said messages through increasingly harsher language as well as violent actions. Some of them were racist in tone, and increasingly widespread on several social media platforms, such as Twitter, where the issue of racial inequality fuels increasing division and hatred. 
Dear White People is a Netflix series, based on a 2014 film of the same title, depicting Winchester University, an ethnically diverse college in the United States of America, where a conflict along racial lines erupts triggered by a "Dear Black People" party, hosted by Pastiche, a humor magazine managed mostly by Caucasian students. At the same University Samantha White, a junior Media Studies major, begins hosting a radio show called "Dear White People" addressed to Caucasian students in order to make them aware of what Blackness means in a judgmental, predominantly white society.

In the second volume, Armstrong-Parker Hall, the dormitory housing a predominantly black student demographic, becomes a common hall for all ethnic groups attending Winchester. As another radio show, Dear Right People starts airing and their narrative, aimed at counteracting "Dear White People", is reinforced by racist tweets coming from a user who calls himself @AltIvyw. Discrepancies increase in Winchester and, in the meantime, some students try to unmask the person behind the nickname @AltIvyw.

The aim of this paper is to present how influential social networking is in society by using Dear White People Vol. 2, as well as to illustrate how the issue of racism increases in magnitude through a narrative that spreads and encourages individuals to take verbal and physical actions against the black minority.

\section{Social networking}

Social networking sites (SNSs) and online social networks (OSNs) refer to web-based services which enable individuals to create a public or semi-public profile within a system and share information with users they want to keep in touch with. ${ }^{1}$ Their use has been growing exponentially. According to Internet World Stats, in 2019 there is a total of 7,716,223,209 users of social media ${ }^{2}$ and the results of research conducted by statista.com show that over two billion people use social networks. ${ }^{3}$ Among them the most notable are Facebook, Instagram, LinkedIn, Twitter, Pinterest or YouTube, which offer their services for different purposes incorporating several information or communication tools, such as mobile connectivity, blogging or microblogging and photo/video-sharing.

The concept of microblogging, as opposed to blogging, refers to "an online platform for posting small messages on the internet in chronological sequence".

${ }^{1}$ D.M. Boyd, N.B. Ellison, "Social network sites: Definition, history and scholarship", Journal of Computer-Mediated Communication 13, 2007, no 1, p. 211.

2 “About Internet World Stats: Stats", Internet World Stats, https://internetworldstats.com/stats. htm (accessed: 10.12.2019).

3 "About Statista.com: Statistics", Statista.com, https://www.statista.com/statistics/272014/ global-social-networks-ranked-by-number-of-users/ (accessed: 10.12.2019). 
These messages are called "microposts" and within them in common use is the convention for labeling a topic called "hashtag". This convention is also conceived as "a form of metadata incorporated into posts" defined by Michele Zappavigna as "searchable talk", that is, a way of finding a topic the user can be interested in. ${ }^{4}$

\subsection{Characteristics of social networks}

\subsubsection{Anonymity}

Anonymity is central to most explanations of both pro- and anti-social CMC (Computer-Mediated Communication) behavior, including self-disclosure according to Adam N. Joinson. ${ }^{5}$ From another perspective, Sara Kiesler et al. conclude that "computer-mediated communication seems to comprise some of the same conditions that are important for deindividuation-anonymity, reduced self-regulation, and reduced self-awareness". ${ }^{6}$ Thus Katelyn Y.A. McKenna and John A. Bargh state the possibility of users expressing their true feelings and thoughts through anonymity. ${ }^{7}$

However, the paradox of anonymity, according to Leonard et al., is that even though it can encourage users to share their honest opinions, it can also lead to harassment or mistreatment of others without fear of reprisal. ${ }^{8}$

\subsubsection{Speed}

Lynnette G. Leonard et al. assign speed to the change of expectations of users about the concepts of time and place when using CMC. The response of a message is required almost immediately without considering the geographic distance traveled by the message. ${ }^{9}$

${ }^{4}$ M. Zappavigna, Discourse of Twitter and Social Media: How We Use Language to Create Affiliation on the Web, London 2012, p. 1.

${ }^{5}$ A.N. Joinson, "Self-disclosure in computer-mediated communication: The role of self-awareness and visual anonymity", European Journal of Social Psychology 31, 2001, no 2, p. 179.

${ }^{6}$ S. Kiesler, J. Siegal, T.W. McGuire, "Social psychological aspects of computer-mediated communication", American Psychologist 39, 1984, no 10, p. 1126.

${ }^{7}$ K.Y.A. McKenna, J. Bargh, "Plan 9 from cyberspace: The implications of the Internet for personality and social psychology", Personality and Social Psychology Review 4, 2000, no 1, p. 62.

${ }^{8}$ L.G. Leonard, L.A. Withers, J.C. Sherblom, "The paradox of computer-mediated communication and identity: Peril, promise and second life", [in:] Interpersonal Relations and Social Patterns in Communication Technologies: Discourse Norms, Language Structures and Cultural Variables, eds. J. Park, E.G. Abels, Hershey 2010, p. 2.

${ }^{9}$ Ibid., pp. 2-3. 
Another feature considered by Leonard et al. is the possibility of communicating with many people at once anywhere in the $\mathrm{CMC}$-accessible world. This characteristic, together with speed enables a kind of communication and collaboration that otherwise would not take place.

Nevertheless, the two mentioned features in CMC allow the users to enact asocial, antisocial, and deviant behaviors that alienate and harm others. ${ }^{10}$

\subsubsection{Experimentation of self-identity}

CMC also allows the user to create a new identity in which gender play is a possibility, where a user can express his "true self". However, it also allows the user to exaggerate, idealize, conceal, and steal identities or hurt individuals or groups - directly or indirectly - by flaming, using cyberhate speech or encouraging others to harm themselves. ${ }^{11}$

\subsection{Twitter as a social networking tool}

The use of social networks by users to communicate with others in CMC is what Zappavigna defines as social interaction or "networking". ${ }^{12}$ Twitter as a microblogging tool has several characteristics such as address and@mention, retweeting and hashtagging. The first one helps the user direct a micropost at another user. ${ }^{13}$ On the other hand, retweeting helps the user republish a tweet within his own tweet. This can amplify the reach of a tweet depending on the person who retweets. ${ }^{14}$ Hashtagging, in turn, enacts a social relation, allowing users to search topics of their interest, at the same sharing time associated values. ${ }^{15}$

\subsection{Politics in social networking}

The use of social media in politics has been present for over a decade. It was in the 2008 presidential campaign when Barack Obama's campaign launched a social network called My.Barack.Obama.com. He also made frequent use of Twit-

\footnotetext{
10 Ibid., p. 3.

11 Ibid.

12 M. Zappavigna, Discourse of Twitter and Social Media: How We Use Language to Create Affiliation on the Web, London 2012, p. 2.

13 Ibid., p. 34.

${ }^{14}$ Ibid., pp. 35-36.

15 Ibid., p. 91.
} 
ter and it is said that Twitter became a legitimate communication channel in the political arena as a result of the 2008 election campaign. ${ }^{16}$

However, the use of Twitter in politics has changed with Donald Trump, since the site became a means to spread his discriminatory narrative, which furthermore made him a charismatic figure and a leader for those who shared his extreme right-wing ideas. He empowered the populist ideology in his country and, in the end, ran for president of the United States, eventually winning the elections (in November 2016). One of his most well-known tweets was the one questioning Obama's citizenship: "An extremely credible source has called my office and told me that @BarackObama's birth certificate is a fraud". ${ }^{17}$ This tweet raises the topic of race and identity, and, by proxy, of inequality, since only a citizen born on American soil can become president.

Another example of Donald Trump's racist rhetoric are his July 2019 tweets directed at four congresswomen from diverse ethnic backgrounds. Their incendiary rhetoric opened a debate about the topic of race and influence of politics on society. The president wrote:

So interesting to see "progressive" Democrat congresswomen, who originally came from countries whose governments are a complete and total catastrophe, the worst, most corrupt and inept anywhere in the world (if they even have a functioning government at all), now loudly and viciously telling the people of the United States, the greatest and most powerful nation on earth, how our government is to be run.

Why don't they go back and help fix the totally broken and crime-infested places from which they came. ${ }^{18}$ Then come back and show us how it is done.

These places need your help badly, you can't leave fast enough. I'm sure that Nancy Pelosi would be very happy to quickly work out free travel arrangements! ${ }^{19}$

\section{The issue of blackness in the United States of America}

\subsection{Concept of race}

Du Bois, activist and journalist, historian and sociologist, novelist, critic, and philosopher, Pan-Africanist, defines race as

${ }^{16}$ Ibid., p. 171.

17 T. Noah, The Donald J. Trump Presidential Twitter Library, London 2018, p. 6.

18 One should note that of the four aforementioned congresswomen, only one was born abroad (and came to the US at a very young age).

19 "News: World-US-Canada", $B B C$, https://www.bbc.com/news/world-us-canada-48982172 (accessed: 5.11.2019). 
a vast family of human beings, generally of common blood and language, always of common history, traditions and impulses, who are both voluntarily and involuntarily striving together for the accomplishment of certain more or less vividly conceived ideals of life. ${ }^{20}$

Some of his detractors such as Lott oppose him, since Du Bois omits the physical similarities of individuals belonging to a race. Nevertheless, Du Bois replies by stating that he was interested in following non-biological criteria in order to provide a more adequate ground for the concept of group identity and adds that what distinguishes groups of people into races is their spiritual and mental differences. $^{21}$

The aim of $\mathrm{Du}$ Bois was, in fact, to be able to speak about "black-blooded people of America" according to the prevailing definitions of race, but, at the same time, leaving him the possibility of questioning the premise that physical differences justify social inequality. ${ }^{22}$

\subsection{The issue of blackness}

In 1733, Cotton Mather, a New England Puritan minister, stated about Black people in his essay The Negro Christianized that: "Indeed their Stupidity is a Discouragement. It may seem unto a little purpose, to Teach, as to wash an Athiopian". ${ }^{23}$ The previous comment came much later than that of Reverend Samuel Davies who, in 1708, wrote

Your Negroes may be ignorant and stupid as to divine Things not for Want of Capacity, but for Want of Instruction; not through their Perverseness, but through your Negligence [...] they are generally as capable of Instruction as the white People. ${ }^{24}$

The issue in question continued flagrantly even after the proclamation of the abolition of slavery in the United States of America in 1865, since in 1884 Senator John T. Morgan of Alabama argued that "increase in black wealth, intelligence and capacity for industrial, commercial and political activity was inevitable, but potentially disastrous, because it could lead only to an increasingly bitter competition with whites". ${ }^{25}$ Thus, it is the fear of Whites of miscegenation and their

${ }^{20}$ W.E.B Du Bois, "The conservation of races", [in:] The Problem of the Color Line at the Turn of the Twentieth Century: The Essential Early Essays, ed. N.D. Chandler, New York 2015, p. 53, reprint of The Conservation of Races, Washington 1897.

${ }^{21}$ T.L. Lott, The Invention of Race. Black Culture and the Politics of Representation, Oxford 1999 , pp. 49-50.

22 Ibid., p. 50.

${ }^{23}$ W.D. Jordan, White over Black, Chapel Hill 1968, p. 187.

24 Ibid., p. 188.

25 G.M. Friedrickson, The Black Image in the White Mind. The Debate on Afro-American Character and Destiny, 1817-1914, New York 1972, p. 228. 
instinctive antipathy what turns back the advance of Black people to the threshold of equality. ${ }^{26}$

Furthermore, in 1894 Frederick Douglass, who was an abolitionist, American social reformer and writer, in the Narrative of the Life of Frederick Douglass, wrote "Why is the Negro Lynched?", where he claimed that the aim of lynching was disenfranchisement and tried to deconstruct the claim that some apologists made of the need of lynching to stop the menace that alleged black rapists were supposed to be for white women in the South. The myth of the black rapist stems from the idea that black people are bestial as a racial group. ${ }^{27}$

It was not until 1955 when a woman named Rosa Parks refused to offer her seat on a bus to a white person that a protest against the segregation in buses called the Montgomery Movement began. Rosa Parks was arrested and then, on Monday December 5th, Dr. Martin Luther King Jr. led the protest group Montgomery Improvement Association (MIA) to boycott the buses and started asking black people not to ride on the bus, but to go by cab or walk to work. ${ }^{28}$ The movement ended on December 20th, 1956, when the integration order reached Montgomery. ${ }^{29}$ This was a peaceful protest for the rights of black people thanks to which, in the words of Martin Luther King Jr.: "The Montgomery Negro had acquired a new sense of somebodiness and self-respect, and had a new determination to achieve freedom and human dignity no matter what the cost".30

\section{Dear White People Vol. 2}

In the second season of Dear White People due to a fire in Davis House, Armstrong-Parker House (predominantly Black) has to accommodate the students from the former (predominantly White).

At the same time a user of a fictional social network called "Chuffah" (similar to Twitter) goes by the name of @AltIvyw and posts racist comments online triggered by the controversy of the origin of the fire and the breaking of a window in Handcock House by Troy Fairbanks, the Dean's son, and the narrative of Samantha White, daughter of a black mother and white father, and host of the radio program "Dear White People". She becomes one of the targets of @AltIvyw.

Amongst@AltIvyw's comments, one of them addressed to Troy Fairbanks, shows the concept of black people as a bestial racial group described by Lott: ${ }^{31}$

${ }^{26}$ Ibid., p. 229.

27 T.L. Lott, op. cit., p. 28.

${ }^{28}$ M.L. King Jr., The Autobiography of Martin Luther King, Jr., ed. C. Carson, London 1999, pp. $50-52$

${ }^{29}$ Ibid., p. 95.

${ }^{30}$ Ibid., p. 99.

31 T.L. Lott, op. cit., p. 28. 
"Dear A-P residents, hide your breakables. Hearing that they let the animal @ TroyBama out of his cage". This idea is also reinforced by @AltIvyw through another post stemming from a violent incident in Armstrong Parker House in which a black student punches another black student in the face: "Black on Black crime at A-P house! What a surprise!"

Furthermore, a heated discussion about the discourse of race starts between Samantha White and @AltIvyw in the fictional "Chuffah" social network. The exchange of messages includes the topic of oppression working both ways and Samantha presenting what oppression looks like reminding @,AltIvyw that Black people were "banned from home ownership", "hung from fucking trees", their houses were "burned to the ground", are "paid less for equal work" and pay "taxes to a police force that shoots them in plain daylight without justice". The response of @AltIvyw is an insult to Samantha: "half-breed bitch". The conversation stops at some point but is lately retaken by @AltIvyw in a post where he uploads a picture of Samantha with her parents and comments: "It's too bad that your dad ruined you by fucking a monkey. Bet she's angry all the time too". The show thus illustrates a notion that, as Karen M. Douglas et al. argue, racial cyberhate attacks are usually targeted toward African Americans ${ }^{32}$. According to white supremacists, the position of Whites as a dominant group is at stake and, therefore, they tend to display magnanimity or covert discrimination including overt racism toward the out-group. ${ }^{33}$

In the meantime, a new radio program called Dear Right People starts airing. Its narrative is characterized by an alt-right, identarian branch of conservatism, supported and inspired by the ideas of @AltIvyw. Opposed to "Dear White People", the former is hosted by three white students, its target group is everyone who feels threatened by non-conservative ideas and its ideology is the defense of whiteness and traditional values. The followers of these ideas are called alt-righters or alternative righters, a concept coined by Richard Spencer, a white supremacist, who supported Donald Trump. ${ }^{34}$ Thus, the username @ AltIvyw is a composition of Alt (Alternative Right), Ivy (the Ivy League) and the W could be referring to the adjective "White". The Ivy League is a group of eight elite sport universities in the north-eastern part of the United States, which have high academic and social status (Penn, Columbia, Harvard, Dartmouth, Yale, Cornell, Brown and Princeton). ${ }^{35}$ Because of that, the director presents a character who hides under a pseudonym that characterizes his profile: a white supremacist at-

${ }^{32}$ K.M. Douglas et al., "Understanding cyberhate: Social competition and social creativity in online white supremacist groups", Social Computer Review 23, 2005, no 1, p. 68.

${ }^{33}$ Ibid., p. 70.

34 C. Fahrenbach, J. Pontius, "Hippe Hasser", Die Zeit Online, https://www.zeit.de/politik/ausland/2016-11/alt-right-usa-donald-trump-ultrarechte-bewegung (accessed: 9.12.2019).

35 "Sports: History", The Ivy League, https://ivyleague.com/sports/2017/8/13/HISTORY_08131 73057.aspx (accessed: 1.11.2019). 
tending an elite institution. The implementation of @AltYvyw in second season of Dear White People also questions the (re)action of those opposing his rhetoric. On the one hand, it is necessary to confront such ideas if they empower discrimination of minorities, but on the other hand the consequences of a rivalry between two parties unable to agree can be devastating as well, especially for the most vulnerable. The latter effects of acting are present in the first chapter of the second season when Sam states that she must take back her narrative. While doing so, she is virtually harassed by @AltYvyw. Social Networking allows us to express ourselves, but also to become potential targets of the mass.

The person hiding under the white supremacist @AltIvyw is Silvio Romo, characterized as a homosexual and Latino, whose political ideology opposes left-wing identity politics. He was the former editor of a college newspaper, The Independent, which was shut down after one of its articles exposed the bigotry of the founders of the paper. Silvio is unmasked by Lionel Higgins, a former journalist of The Independent who wrote the article which triggered the cancellation of the newspaper. Silvio confesses that he aimed, at the beginning, at getting "Likes", but afterward, his goal was being the voice of other people, in this case exactly the group of ideological opponents of "Dear White People". Once he is discovered, he continues his hate-filled rhetoric without losing his followers, who defend and support him.

Gabe Mitchel, former boyfriend of Samantha White, starts a documentary called "Am I a racist?" in which he interviews several black students asking them about their experiences in society related to their skin color. His goal is to understand what he, as a white person, can do in contributing to stop racism. In the process, he also interviews Samantha and she states: "Silvio is what happens when you challenge an unjust status quo. The people who benefit from it want to silence those who want to change it". The message that Samantha is trying to convey is that blaming the majority in society triggers radical opinions blaming minorities and engages an aggressive debate between two extremes where understanding is difficult to achieve.

\section{Conclusion}

In this study, it has been shown how powerful Social Networking can be and that even if it can have positive effects, characteristics such as anonymity also enable the possibility of creating social division, causing psychological harm and spreading hatred. The disinhibition of the user on CMC allows the user to freely speak up, neither considering the language used nor the accountability for the form used to express his ideas. Even though the behavior can stem from the background of the user (education, economic situation, experiences, political and religious beliefs, etc.) it does not have to. As has been shown in the analysis of volume 2 of Dear White People, Silvio represents an elite student with socio-political concerns who takes advantage of the possibilities offered by Social Networking. 
Dear White People Vol. 2 presents a massive criticism to the misuse of CMC and the effects on the topic of race, presenting instances in which African Americans are still considered as they were in the past, as a race that is moved by instinct more than reasoning. It also presents the idea of oppression toward Whites, the fear of the dominance of the out-group over them. The battle through social media has greater practical effects, since it emboldens a silenced part of society which believes in racial inequality and tends to normalize it in order not to feel threatened.

Currently, politics plays a significant role in social media and populist movements are spreading dramatically. Fear of dominance is used by politicians who prey on inequality while calling themselves tolerant. Immigration is portrayed as a threat to the working market and, depending on the ethnic group, religious beliefs might also be seen as threatening for being different. The arrival of Donald Trump and his rise to power created a new offspring of white nationalists who believe that acting like such a leader is normal behavior.

The depiction of society in Dear White People shows the possibilities offered by TV to raise awareness of the current social situation and the evolution of society. The diversity of characters representing stereotypes and lines of thought also allow the spectator to relate to and empathize with one or more characters, leading to a critical reflection about his/her position in society and his/her attitude toward the issue of racism. Dear White People addresses in its first two volumes oppression, culture appropriation, police brutality, the resurgence of white supremacy and the use of social media to spread populist ideology. Some of these topics have been present in the history of the United States of America and still are. Malcom X, Martin Luther King Jr. and Rosa Parks fought for the rights of Black people, but movements such as Black Lives Matter show that the problematic of racial inequality still exists. There is still a long way to go in order to achieve equality and, as long as there are prejudices and in the eyes of the majority some minorities are "different", there is always going to be exclusion.

\section{Drodzy biali! Vol. 2 - media społecznościowe jako narzędzie egzekwowania nierówności rasowej}

\section{Abstrakt}

W ostatnich czasach media społecznościowe były wykorzystywane jako środek szerzenia niepokojącej narracji przez wzbudzające gniew, prowokacyjne i szkodliwe komunikaty. Niektóre z nich, zamieszczane przez wpływowych ludzi u władzy, doprowadziły do wzmocnienia pozycji jednostek, które wyraziły ewidentne wsparcie dla takich komunikatów z użyciem zarówno coraz ostrzejszego języka, jak i brutalnych czynów. Część z nich miała rasistowski charakter i szybko rozprzestrzeniła się na kilku portalach społecznościowych, takich jak Twitter, gdzie problem nierówności społecz- 
nych jest wykorzystywany w procesie zwiększania podziałów i podsycania nienawiści. Drodzy biali! to serial Netfliksa oparty na filmie o tym samym tytule z 2014 roku, przedstawiający fikcyjny Uniwersytet Winchestera, zróżnicowaną etnicznie amerykańską uczelnię, w której wybucha konflikt rasowy. Studentka medioznawstwa na rzeczonym uniwersytecie, Samantha White, rozpoczyna nadawanie radiowego programu „Drodzy biali”, mającego w założeniu wytłumaczyć studentom rasy kaukaskiej, z czym wiąże się bycie czarnym w nietolerancyjnym, zdominowanym przez białych społeczeństwie. Celem artykułu jest zaprezentowanie wagi mediów społecznościowych na przykładzie sezonu drugiego Drogich białych, jak też wykazanie, w jaki sposób problem rasizmu zwiększa swoją skalę przez rozprzestrzeniającą się narrację, która zachęca jednostki do słownego i fizycznego napastowania członków czarnej mniejszości.

Słowa-klucze: Drodzy biali, media społecznościowe, rasizm, Netflix, telewizja, polityka, tożsamość

\section{Bibliography}

Boyd D.M., Ellison N.B., "Social network sites: Definition, history and scholarship", Journal of Computer-Mediated Communication 13, 2007, no 1, pp. 210-230.

Douglas K.M, Mcgarty C., Bliuc A., Girish L., "Understanding cyberhate: Social competition and social creativity in online white supremacist groups", Social Computer Review 23, 2005, no 1, pp. 68-76.

Du Bois W.E.B., "The conservation of races", [in:] The Problem of the Color Line At the Turn of the Twentieth Century: The Essential Early Essays, ed. N.D. Chandler, New York 2015, pp. 51-65, reprint of The Conservation of Races, Washington 1897.

Friedrickson G.M, The Black Image in the White Mind. The Debate on Afro-American Character and Destiny, 1817-1914, New York 1972.

Joinson A.N., "Self-disclosure in computer-mediated communication: The role of self-awareness and visual anonymity", European Journal of Social Psychology 31, 2001, no 2, pp. 177-192.

Jordan W.D., White over Black, Chapel Hill 1968.

Kiesler S., Siegal J., McGuire T.W., "Social psychological aspects of computer-mediated communication", American Psychologist 39, 1984, no 10, pp. 1123-1134.

King M.L. Jr., The Autobiography of Martin Luther King, Jr., ed. C. Carson, London 1999.

Leonard L.G., Withers L.A., Sherblom J.C., "The paradox of computer-mediated communication and identity: Peril, promise and second life", [in:] Interpersonal Relations and Social Patterns in Communication Technologies: Discourse Norms, Language Structures and Cultural Variables, eds. J. Park, E.G. Abels, Hershey 2010, pp. 1-17.

Lott T.L., The Invention of Race. Black Culture and the Politics of Representation, Oxford 1999.

McKenna K.Y.A., Bargh J., "Plan 9 from cyberspace: The implications of the Internet for personality and social psychology", Personality and Social Psychology Review 4, 2000, no 1, pp. 57-75.

Noah T., The Donald J. Trump Presidential Twitter Library, London 2018.

Zappavigna M., Discourse of Twitter and Social Media: How We Use Language to Create Affiliation on the Web, London 2012. 
“About Internet World Stats: Internet database", Internet World Stats, https://internetworldstats. com/stats.htm.

"About Statista.com: Internet database", Statista.com, https://www.statista.com/statistics/272014/ global-social-networks-ranked-by-number-of-users/.

Fahrenbach C., Pontius J., "Hippe Hasser", Die Zeit Online, https://www.zeit.de/politik/ausland/2016-11/alt-right-usa-donald-trump-ultrarechte-bewegung.

"News: World-US-Canada", $B B C$, https://www.bbc.com/news/world-us-canada-48982172.

"Sports: History", Ivy League, https://ivyleague.com/sports/2017/8/13/HISTORY_0813173057. aspx.

Antonio Gallardo Gracia - holds an MA in Spanish Philology (Universitat Autònoma de Barcelona) and a Master's Degree in Teaching Spanish as a Foreign Language (Universidad Antonio de Nebrija). He has been working as a Spanish and Catalan teacher in several countries and institutions. In Illinois (USA) he worked as a Spanish Teacher at Lincoln Middle School (PPS District 150), in Kraków (Poland) as a Spanish Teacher at the Cervantes Institute and in Galway (Ireland) at the National University of Ireland as a Spanish and Catalan Teacher. Currently he works at the Universität Würzburg (Germany) as a Spanish and Catalan Teacher. Throughout his research career he has focusi on the Teaching of Foreign Languages, but he is also interested in Luis Buñuel and Surrealism, as well as Latin-American History and Culture. antonio.gallardo_gracia@uni-wuerzburg.de

Antonio Gallardo Gracia — uzyskał tytuł magistra iberystyki (Universitat Autònoma de Barcelona) i tytuł magistra w zakresie nauczania hiszpańskiego jako języka obcego (Universidad Antonio de Nebrija). Pracował jako lektor języka hiszpańskiego i katalońskiego w kilku krajach i instytucjach. W Illinois (USA) pracował jako nauczyciel hiszpańskiego w Lincoln Middle School (PPS District 150), w Krakowie jako nauczyciel hiszpańskiego w Instytucie Cervantesa oraz w Irlandzkim Narodowym Uniwersytecie w Galway jako lektor hiszpańskiego i katalońskiego. Obecnie jest zatrudniony na Uniwersytecie w Würzburgu (Niemcy) jako lektor języka hiszpańskiego i katalońskiego. W swoich badaniach skupia się na nauczaniu hiszpańskiego jako języka obcego, ale jego zainteresowania obejmują również twórczość Luisa Buñuela, surrealizm oraz historię i kulturę Ameryki Łacińskiej. 